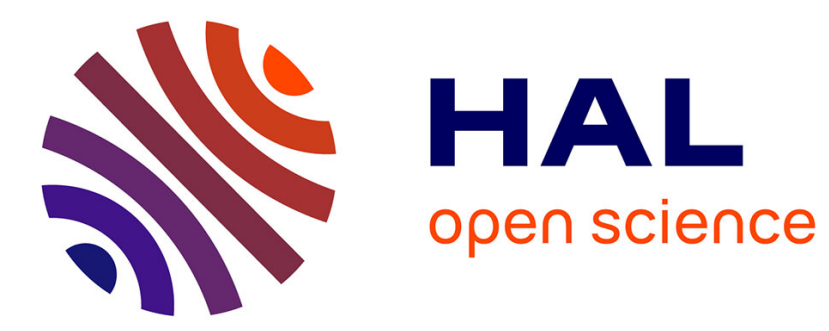

\title{
Hypospadias: interactions between environment and genetics
}

\author{
N. Kalfa, P. Philibert, L.S. Baskin, C. Sultan
}

\section{To cite this version:}

N. Kalfa, P. Philibert, L.S. Baskin, C. Sultan. Hypospadias: interactions between environment and genetics. Molecular and Cellular Endocrinology, 2011, 335 (2), pp.89. 10.1016/j.mce.2011.01.006 . hal-00672294

\section{HAL Id: hal-00672294 \\ https://hal.science/hal-00672294}

Submitted on 21 Feb 2012

HAL is a multi-disciplinary open access archive for the deposit and dissemination of scientific research documents, whether they are published or not. The documents may come from teaching and research institutions in France or abroad, or from public or private research centers.
L'archive ouverte pluridisciplinaire HAL, est destinée au dépôt et à la diffusion de documents scientifiques de niveau recherche, publiés ou non, émanant des établissements d'enseignement et de recherche français ou étrangers, des laboratoires publics ou privés. 


\section{Accepted Manuscript}

Title: Hypospadias: interactions between environment and genetics

Authors: N. Kalfa, P. Philibert, L.S. Baskin, C. Sultan

PII:

S0303-7207(11)00027-X

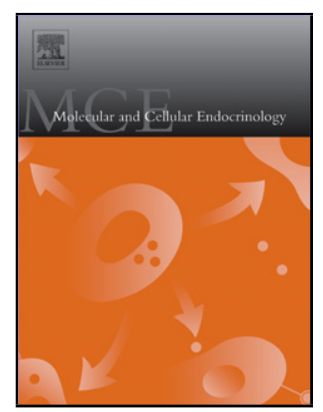

DOI: doi:10.1016/j.mce.2011.01.006

Reference: MCE 7745

To appear in: Molecular and Cellular Endocrinology

Received date: $15-10-2010$

Revised date: 3-1-2011

Accepted date:

7-1-2011

Please cite this article as: Kalfa, N., Philibert, P., Baskin, L.S., Sultan, C., Hypospadias: interactions between environment and genetics, Molecular and Cellular Endocrinology (2010), doi:10.1016/j.mce.2011.01.006

This is a PDF file of an unedited manuscript that has been accepted for publication. As a service to our customers we are providing this early version of the manuscript. The manuscript will undergo copyediting, typesetting, and review of the resulting proof before it is published in its final form. Please note that during the production process errors may be discovered which could affect the content, and all legal disclaimers that apply to the journal pertain. 


\section{Hypospadias: interactions between environment and genetics}

N Kalfa ${ }^{1,2}$, P Philibert ${ }^{1}$, LS Baskin ${ }^{3}$, C Sultan $^{1,4}$

1- Service d'Hormonologie, Hôpital Lapeyronie, CHU de Montpellier et UM1, Montpellier, France

2- Service de Chirurgie et Urologie Pédiatrique, Hôpital Lapeyronie, CHU de Montpellier et UM1, Montpellier, France

3- Center for the Study and Treatment of Hypospadias, Department of Urology, University of California San Francisco Children's Medical Center, San Francisco, California, USA

4- Unité d'Endocrinologie et Gynécologie Pédiatriques, Service de Pédiatrie, Hôpital Arnaud de Villeneuve et UM1, CHU de Montpellier, France

Address for correspondence and reprint requests:

Pr Charles Sultan

Unité d'Endocrinologie-Gynécologie Pédiatriques, Service de Pédiatrie 1 Hôpital Arnaud de Villeneuve, CHU Montpellier, 34295 Montpellier, France

Tel: 33467338696 Fax: 33467048573 E-mail: c-sultan@chu-montpellier.fr 
Hypospadias is one of the most common congenital malformations. It is considered to be a mild form of the 46,XY disorders of sex development (DSD), but its precise etiology remains to be elucidated. Compromised androgen synthesis or effects can cause this frequent malformation, although the mutational analyses of the genes involved in androgen actions have identified abnormalities in only a very small portion of patients. The overwhelming majority of cases remain unexplained and hypospadias may be a highly heterogeneous condition subject to multiple genetic and environmental factors. We here review the recent advances in this field and discuss the potential interactions between the environment and genetics.

Key words

Hypospadias, etiology; Hypospadias, genetics; Environment; Endocrine disruptor; Polymorphism, single nucleotide. 
Hypospadias is defined as a defect in the development of the ventral aspect of the penis along with an ectopic opening of the urethral meatus. Its incidence ranges from 1/1000 to $1 / 100$ [1], with significant variations according to ethnic origin, making it one of the most frequent developmental defects. In most cases, the degree of hypospadias is relatively mild and a specific endocrine cause is not sought or is not found[2]. However, four main elements are involved in male genital construction and may contribute to this malformation[3,4]: (1) the genetic and endocrine background of the child, principally the genes of phallic development, gonadal steroid synthesis (mainly testosterone and its $5 \alpha$ reduced form, dihydrotestosterone, DHT), and the responsiveness to these hormones. The genital tubercle thus grows under the influence of androgens and any alteration in androgen production or receptors may produce a hypospadiac penis; (2) the placenta, which orchestrates the hormonal climate, especially during the first part of gestation; (3) the mother, with her own hormonal production and possible disorders; and (4) the environment of mother and child, which may also interfere in this fine balance[5,6].

Over the last 30 years, male reproductive health has been altered, with deterioration in sperm count and an increasing number of cases of undescended testes, testicular cancers and hypospadias[9]. This phenomenon has raised some concerns regarding environmental chemicals such as the products of industrial and agricultural development $[10,11]$. We here review the role of the environment in the occurrence of hypospadias and the interaction between environmental factors and genetics. 


\section{$\underline{\text { I Genetic background }}$}

Before evaluating the role of the environment, it should be acknowledged that several arguments are in favor of a predominant role for the genetic background. Familial clustering is seen in about $10 \%$ of the cases[12-15], and the recurrence risk in the male siblings of an affected patient is about $15 \%$ [16-18]. Seven percent of the fathers of children with hypospadias are also affected[19]. The risk of recurrence is also found to aggregate in more distant relatives. Using Danish health registers, Schnack et al. identified 5,380 boys diagnosed with hypospadias in a cohort of 1,201,790 boys born in the period 1973-2005. The risk ratios of hypospadias for male first-, second-, and third-degree relatives of a hypospadiac case were, respectively, $11.6 \%, 3.27 \%$, and $1.33 \%$. The risk of recurrence for the next male sibling depends on the severity of the hypospadias [16]. Segregation analysis suggests that hypospadias might be due to monogenic effects in a small proportion of the families, whereas a multifactorial mode of inheritance was reported to be more likely in the majority of families[20]. Finally, some of the 200 syndromes that include hypospadias have known genetic bases and shed light on the molecular mechanisms involved in genital development. [21,22]

The environment may act on the genes that contribute to the occurrence of hypospadias at several levels.

1- Level of phallus development: Homeobox genes A (HOXA) and D (HOXD) participate in the development of the phallus since knock-out of these genes in mice induces a malformation in the external genitalia consistent with hypospadias[23]. In humans, the hand-foot-genital syndrome (HFGS)[24,25] is related to mutations of HomeoboxA13 (HOXA13). HOXA13 allows the normal expression of fibroblast growth factor (FGF) 8 
and bone morphogenetic protein (BMP) 7 in the developing urethral epithelium in mice, thus modulating androgen receptor expression and glans vascularization[3]. The FGF gene family, especially FGF10[26], is also implicated in the development of external genitalia in mice[27]. In humans, polymorphisms of FGF8, FGF10 and FGFR2 may be associated with an increased risk of hypospadias[28].

2- Level of testicular determination: The genes leading to testicular dysgenesis are a cause of hypospadias. Severe hypospadias along with other genital abnormalities[29,30] can reveal heterozygous mutations of Wilms tumor 1 (WT1). SOX9, DMRT1 and GATA4 encode transcription factors acting immediately before the differentiation of the gonad into testis. Mutations of these genes induce testicular dysgenesis and are associated with 46,XY disorders of sex differentiation (DSD), including severe hypospadias [31-34]. Variation in gene dosage, as shown in $46, \mathrm{XX}$ and $46, \mathrm{XX}$ d17 patients with SOX9 duplication, can also induce penoscrotal hypospadias [31].

3- Level of androgen biosynthesis: Mutations in the LH receptor gene (inducing a Leydig cell hypoplasia) and the 5a-reductase gene (inducing a defect of dihydrotestoterone synthesis) induce hypospadias, most often in a severe form with associated cryptorchidism and/or micropenis [32,35,36] [37]. MAMLD1 (mastermind-like domain containing gene) is another candidate gene that seems to modulate the synthesis of testosterone around the critical period of sex differentiation. MAMLD1 is expressed in the male gonad in mice, and it augments testosterone production and contains the SF1 target sequence[38]. Fukami et al.[39] identified three nonsense mutations in four individuals with 46,XY DSD including micropenis, bifid scrotum and penoscrotal hypospadias. Genetic variants of MAMLD1 were further shown to be present in patients 
with isolated hypospadias[40], as confirmed by Chen et al. [41], who identified five nonsynonymous mutations, some of them as polymorphisms.

4- Level of androgen action: Mutations in the androgen receptor gene (AR) have been found in patients with either severe forms of hypospadias[42-44] or other signs of undervirilzation, such as cryptorchidism[45] or micropenis[46,47]. Mutation of the AR gene in partial androgen insensitivity syndrome is found only in $20 \%$ to $30 \%$ of cases and the phenotype remains particularly variable $[46,48]$.

\section{$\underline{\text { II Environment }}$}

II-1 Arguments for an environmental contribution

Several findings in both animal and human studies raise suspicion of an environmental contribution to this malformation. Hypospadias, whether associated with micropenis or not, has been reported in numerous wildlife species when the habitat is contaminated by pesticides[49]. The effects of prenatal xenoestrogens on animal male reproductive tract development have been studied by several groups. Male rat pups exposed to DES during gestation (at concentrations similar to those measured in first-trimester human fetal tissues) developed hypospadias[50,51]. Hypospadias was also found in male rodents after maternal treatment with vinclozolin (dose-response effect)[52], and similar findings were recorded for prenatal exposure to polychlorinated biphenyls (PCB), phthalates and dioxin[52-54].

Despite some inaccurate registers which under-evaluate the number of hypospadias cases and the variable geographical distribution of the malformation[55], several reports suggest an increase in hypospadias over the last 20 years[56]. Boisen[57] performed a 
prospective cohort study and found a high prevalence (1\%) of hypospadias in the Danish population of male newborns, whereas the prevalence was reported to be $0.73 \%$ in the Netherlands in a cross-sectional study[58]. A prospective case-control study of 1,442 male newborns identified 16 cases of middle and posterior hypospadias $(1.1 \%)$ in the south of France[59]. More recent reports have also described an increased incidence[60,61], but epidemiological studies nevertheless give divergent results about whether the trend of hypospadias is increasing and thus raise questions about temporal trends [62][63]. Aho et al. [64] identified all patients in the national hospital discharge registry who had been born in the period 1970-1986 and surgically treated for hypospadias before the age of 9 years. They calculated the cumulative prevalence by dividing the number of patients by the number of male births and found that the prevalence of hypospadias in Finland remained constant throughout the study period but appeared to be approximately three times higher than previously reported. Improvements in completing the registration forms may account for a substantial proportion of the higher prevalence of hypospadias, according to these authors. Martinez Frias et al. [65] found similar results using the Spanish Collaborative Study of Congenital Malformations (ECEMC) registry to analyze the prevalence in two different periods.

This phenomenon has raised some concerns regarding environmental chemicals, such as industrial and agricultural products. Two epidemiological studies reported a possible relationship between exposure to pesticides and hypospadias. Kristensen reported a moderate increase in the odds ratio (OR) for hypospadias in individuals exposed to farm chemicals (OR $=1.51,95 \%$ confidence interval, 1.00-2.26)[66], and Weidner[67,68] concluded that maternal farming or gardening led to a slightly increased risk of hypospadias $(\mathbf{O R}=\mathbf{1 . 2 7}$, 95\% confidence interval, 1.14-2.47). Residence in the vicinity of hazardous waste-disposal 
sites has been associated with a high incidence of hypospadias[69,70]. Similarly, an increased rate of hypospadias was reported in boys from parents exposed to dioxin after the Seveso industrial accident[71]. A vegetarian diet in pregnant women was reported to carry a significant risk of hypospadias[72] $(\mathrm{OR}=\mathbf{4 . 9 9}, \mathbf{9 5 \%}$ confidence interval, 2.10-11.88). A study in Western Minnesota[73] found a higher rate of congenital abnormalities in infants conceived in spring when herbicides are usually widely used. Birth rates with urogenital abnormalities, as well as abnormalities in other systems, were significantly increased in highuse areas. Another study[74] also suggested a possible gene-environment interaction at work in this agricultural region. A total of $22 \%$ of the families in which the father applied the herbicides had more than one child with a birth defect.

Although most investigations of congenital anomalies have focused on major structural defects, recent epidemiology finds subtle developmental defects in genital masculinization. Anogenital distance, a reflection of male reproductive tract development which is reduced in hypospadiac patients[75], was found to be reduced in cases of prenatal exposure to phtalates[75,76].

Last, some of these substances, like DES (diethylstilbestrol), were observed to increase the hypospadias incidence in the second generation, suggesting a transgenerational effect[77].

II-2 Substances

Several substances in the environment may potentially interfere with male genital development because of their similarity to hormones. Although there is a long list of suspicious substances contained in herbicides, fungicides, insecticides, and industrial by- 
products or end-products (plasticizers, cosmetics, paints, etc.), none of them has been clearly identified as responsible for hypospadias. Various pollutants potentially involved in the abnormal development of the genital tubercle include: chlorinated pesticides (DTT, Lindane), polychlorinated biphenyl, methoxychlor, phenolic derivatives, nonylphenol, endosulfan, atrazine, phthalates, dioxine, furans[78], xenoestrogens, phytoestrogens, and mycoestrogens [79].

II-3 Contamination routes

Humans are in constant contact with many of these substances[73,80] as they are found in water, soil, food and air[81,82]. These pollutants enter the body either by ingestion, inhalation, or adsorption, or they may be conveyed through the placenta. Individual exposure varies with dietary habits, life style, and work. Most of these pollutants are lipophilic and are stored in body fat for a lifetime[83]. They are also found in breast milk[84] and in the amniotic fluid. Since most of these chemicals use the same pathways as natural hormones, they have been named xenoestrogens and/or endocrine disrupting chemicals (EDC).

\section{Interactions between environment and genetics}

III-1 Types of action of environmental pollutants

Environmental pollutants exhibit several genomic and non-genomic actions. They bind to the nuclear receptors such as estrogen receptors $\alpha$ and $\beta(E R \alpha / E R \beta)$, inducing transcription activation (or repression) of specific gene expression[85,86]. Non-genomic actions are mediated by a plasma membrane estrogen or androgen receptor. Xenoestrogens have both 
estrogenic and antiandrogenic actions and compete with natural androgens for the ligandbinding domain (LBD) of the AR gene[87]. They also induce more potent estrogenic metabolites. In addition to these receptor-mediated actions, EDCs may affect synthesis, metabolism, excretion, and binding of endogenous hormones to SHBG, and they have the capacity to inhibit the transcription of androgen-dependent genes $[88,89]$. Finally, an epigenetic action has been demonstrated[90].

A major point regarding the action of environmental toxicants in inducing hypospadias is the cumulative effects of multiple low-dose exposures. The cumulative effects of in utero administration of mixtures of "antiandrogens" on male rat reproductive development has previously been demonstrated[91]. In this study, the complex mixture behaved in a dose-additive manner, and compounds that acted by disparate mechanisms of toxicity displayed cumulative effects when present in combination. This situation could reflect real environmental conditions, in which several chemicals that do not act via a common cellular mechanism of action are present together and disrupt fetal tissues during sexual differentiation in a dose-additive manner[92,93].

III-2 Candidate genes implicated in the susceptibility to environment

The dialogue between genes and the environment may include variations in gene expression and variations in receptivity. Genetic variants (polymorphisms) may modulate the individual susceptibility to the external environment.

\section{III-2-1 Dysregulation of gene expression}

The expression of gonadal development genes varies according to the exposure to estrogen-like substances. Experimental studies in both rats and mice have demonstrated that 
estrogens can directly inhibit testicular steroidogenesis in the fetus[94]. Consistent with this finding, studies have reported an increase in the incidence of hypospadias in male mice that were exposed in utero to DES or ethinyl estradiol[95]. In addition to this mechanism, a complete loss of androgen receptor protein expression was found to be a more severe effect of these substances[96].

Xenoestrogens also act as endocrine disruptors. Molecular analyses in fetal rat testes after in utero exposure to phtalates have shed light on the potential mechanisms via which phtalates suppress testicular testosterone production. Several key genes involved in steroidogenesis were disrupted after in utero exposure to monobutyl phthalate and monoethyl hexyl phthalate, such as StAR, HMG-CoA synthase, SRB1 and the steroidogenic enzymes Cyp11a, 3beta HSD and Cyp 17 [97] [98,99]. Linuron, a urea-based pesticide, acts as an antiandrogen. It antagonizes rat and human AR, inhibits androgen-induced gene expression, and reduces testosterone production by effects on LH receptor expression [100] [101]. Dioxin also suppresses StAR and CYP17 mRNA expression later in gestation, possibly through suppression of LH secretion[102] [103].

Three estrogen-responsive genes are suspected to be at the crossroads of environment and genetics in hypospadias for several reasons: ATF3, ER $\alpha$ and TGF- $\beta 1$. ATF3 is the most upregulated estrogen-dependent gene in the foreskin of hypospadiac patients [104]. Immunohistochemical analysis on human foreskin confirmed that the majority of the hypospadiac samples were positive for expression of ATF3[105]. Both animal and in vitro studies confirmed these findings. In vitro exposure to ethinyl estradiol increases expression and promoter activity of ATF3 in human foreskin fibroblasts [106]. In a murine model, fetal exposure to estrogen increases the level of ATF3 messenger RNA [107], whereas fetal exposure to DEHP (Di-(2-ethylhexyl) phthalate, a common plasticizer, activates the transcription and transduction of the ATF3 gene [108]. Since 
ATF3 is implicated in cell cycle suppression, its upregulation may interfere with urethra formation[109], as suggested by the dysregulated apoptosis in the murine model described above [108].

Exogenous administration of estrogens also results in an increased expression of ER $\alpha$ (but not ER $\beta$ )[110]. Expression of TGF- $\beta 1$ is also modulated by endocrine disruptors. Reverse-transcription polymerase chain reaction (RT-PCR) and Western blot studies have shown that the expression of TGF- $\beta 1$ is upregulated in DEHP-treated mice along with a significant inhibition of male fetal genital tubercule[108].

III-2-2 Gene polymorphisms

Polymorphisms of steroid receptors may modulate the response to toxic substances. An increased GGN trinucleotide repeat in the AR gene has been found to reduce its transcriptional activity in hypospadiac patients[111,112]. The role of amplification of the CAG repeats remains to be determined [113] and may be associated with undermasculinized genitalia, including hypospadias[114]. For some authors, the V89L variant of the SRD5A2 gene is a risk factor for hypospadias [115], whereas for others it is not [116]. Polymorphisms of the estrogen receptor may also facilitate the deleterious effects of xenoestrogens since their effects are mainly mediated through this receptor. The AGAGA haplotype of the estrogen receptor 1 (ESR1) gene is strongly associated with hypospadias[117]. The ESR1 C-A haplotype, for ESR1 XbaI and ESR2 2681-4A>G, respectively, increases the risk of malformation, as well[118]. An increased number of CA repeats (and subsequently increased ER activity) also augments the risk of malformation[119], and more recently we identified ATF3 polymorphisms in patients with isolated hypospadias[120]. The data regarding the association of polymorphisms with 
hypospadias should nevertheless be interpreted with caution. In a large series of 620 Caucasian hypospadiac patients, Van der Zanden et al. [116] failed to confirm the association of single nucleotide polymorphisms (SNPs) in SRD5A2 and ESR1 with hypospadias. The SNPs in ESR2 and ATF3 were even found to be associated in the opposite direction compared with earlier publications. These divergent results confirm that genetic association approaches need to be replicated in very large samples.

\section{III-2-3 Xenoestrogen and epigenetics}

Changes in the epigenetic background induced by synthetic estrogens could be a significant factor in the susceptibility to disease development. The epigenetics appear to involve altered DNA methylation. The primordial germ cells undergo demethylation during migration and early colonization of the embryonic gonad, followed by remethylation starting at the time of sex determination in a sex-specific manner $[121][122,123]$. The exposure of the pregnant mother at the time of fetal sex determination may be sufficient to alter the remethylation of the germ line in the male fetus and permanently reprogram the imprinted pattern of DNA methylation in boys[124].

Bredfeldt et al. [90] recently showed that 17beta-estradiol (E2) and the xenoestrogen diethylstilbestrol (DES) reduce levels of trimethylation of the lysine residue 27 on histone $\mathbf{H 3}$. Interestingly, the modulation of methylation by these substances is mediated by membrane-activated estrogen receptor signaling-through phosphatidylinositol 3 and kinase/protein kinase B-and occurs during windows of uterine development that are susceptible to developmental reprogramming. Activation of this nongenomic pathway has also been shown to reprogram the expression profile of estrogen-responsive genes in uterine myometrial cells. This mechanism for 
developmental reprogramming caused by early-life exposure to xenoestrogens may contribute to the modulation of the epigenetic machinery during tissue development.

\section{$\underline{\text { IV Limitations and questions }}$}

Although numerous studies point toward a major role for the environment in hypospadias, two limitations should be considered before attempting to draw definitive conclusions. First, caution should be exercised when extrapolating from murine experiments to humans. In these experiments, xenoestrogens induced hypospadias in male offspring exposed in utero, but the doses given to animals may not be comparable to environmental exposure. Second, several epidemiological studies have reported contradictory results, as noted above $[62,64,65]$. Epidemiological studies on maternal exposure are also inconclusive. Contrary to previously cited studies [67] [125], some reports did not confirm any significant risk of hypospadias when mothers were exposed to DTT[62,126]. Moreover, the critical level of exposure to EDCs was not assessed in any of the epidemiological studies implicating the environment[67] [125]. No relationship was identified between polybrominated biphenyl (PBB) [127] or polychlorinated biphenyl (PCB) exposure[128] and hypospadias. A recent meta-analysis indicated only a modestly increased risk of hypospadias associated with pesticide exposure[129].

\section{Conclusion}

The study of hypospadias is of interest for several reasons. It is an easily diagnosed malformation and, although minor, it recapitulates the pathophysiology of the disorders of sex development; the investigation of hypospadias thus offers insight into the mechanisms of sex 
determination and differentiation. Moreover, because hypospadias is at the crossroads of genetics and environment, it is a model for exploring genetic and environmental interactions (Figure 1). The environmental data to date, however, should be interpreted with caution. Indisputable proof of the detrimental effects of the environment is still pending and no single EDC has been identified as a cause of hypospadias in humans. Hypospadias nevertheless remains a sentinel of the effects of the environment through genetics, both at the present time and for the next generation.

\section{Legend}

Table 1: Summary of genetic variants associated with an increased risk of hypospadias

Figure 1: Schematic view of the intrication between environment and actors of genital masculinisation.

\section{References}

[1] Manson, J.M. and Carr, M.C. (2003) Molecular epidemiology of hypospadias: review of genetic and environmental risk factors. Birth Defects Res A Clin Mol Teratol 67, 825-36.

[2] Rey, R.A., Codner, E., Iniguez, G., Bedecarras, P., Trigo, R., Okuma, C., Gottlieb, S., Bergada, I., Campo, S.M. and Cassorla, F.G. (2005) Low risk of impaired testicular Sertoli and Leydig cell functions in boys with isolated hypospadias. J Clin Endocrinol Metab 90, 6035-40.

[3] Mouriquand, P. (2007) Etiological Aspects of Hypospadias. Dialogues in Pediatric Urology 28, 1.

[4] Kalfa, N., Philibert, P. and Sultan, C. (2009) Is hypospadias a genetic, endocrine or environmental disease, or still an unexplained malformation? Int J Androl 32, 187-97. 
[5] Yiee, J.H. and Baskin, L.S. (2010) Environmental factors in genitourinary development. J Urol 184, 34-41.

[6] Wang, M.H. and Baskin, L.S. (2008) Endocrine disruptors, genital development, and hypospadias. J Androl 29, 499-505.

[7] Shima, H., Ikoma, F., Terakawa, T., Satoh, Y., Nagata, H., Shimada, K. and Nagano, S. (1979) Developmental anomalies associated with hypospadias. J Urol 122, 619-21.

[8] Carmichael, S.L., Shaw, G.M., Nelson, V., Selvin, S., Torfs, C.P. and Curry, C.J. (2003) Hypospadias in California: trends and descriptive epidemiology. Epidemiology 14, 701-6.

[9] Toppari, J., Virtanen, H.E., Main, K.M. and Skakkebaek, N.E. (2010) Cryptorchidism and hypospadias as a sign of testicular dysgenesis syndrome (TDS): environmental connection. Birth Defects Res A Clin Mol Teratol 88, 910-9.

[10] Nelson, C.P., Park, J.M., Wan, J., Bloom, D.A., Dunn, R.L. and Wei, J.T. (2005) The increasing incidence of congenital penile anomalies in the United States. J Urol 174, 1573-6.

[11] Kalfa, N., Sultan, C. and Baskin, L.S. (2010) Hypospadias: etiology and current research. Urol Clin North Am 37, 159-66.

[12] Chen, Y.C. and Woolley, P.V., Jr. (1971) Genetic studies on hypospadias in males. J Med Genet 8, 153-9.

[13] Czeizel, A., Toth, J. and Erodi, E. (1979) Aetiological studies of hypospadias in Hungary. Hum Hered 29, 166-71.

[14] Kallen, B., Bertollini, R., Castilla, E., Czeizel, A., Knudsen, L.B., Martinez-Frias, M.L., Mastroiacovo, P. and Mutchinick, O. (1986) A joint international study on the epidemiology of hypospadias. Acta Paediatr Scand Suppl 324, 1-52.

[15] Fredell, L., Iselius, L., Collins, A., Hansson, E., Holmner, S., Lundquist, L., Lackgren, G., Pedersen, J., Stenberg, A., Westbacke, G. and Nordenskjold, A. (2002) Complex segregation analysis of hypospadias. Hum Genet 111, 231-4.

[16] Bauer, S.B., Bull, M.J. and Retik, A.B. (1979) Hypospadias: a familial study. J Urol 121, 474-7.

[17] Stoll, C., Alembik, Y., Roth, M.P. and Dott, B. (1990) Genetic and environmental factors in hypospadias. J Med Genet 27, 559-63.

[18] Asklund, C., Jorgensen, N., Skakkebaek, N.E. and Jensen, T.K. (2007) Increased frequency of reproductive health problems among fathers of boys with hypospadias. Hum Reprod 22, 2639-46.

[19] Monteleone Neto, R., Castilla, E.E. and Paz, J.E. (1981) Hypospadias: an epidemiological study in Latin America. Am J Med Genet 10, 5-19.

[20] Svensson, J. (1979) Male hypospadias, 625 cases, associated malformations and possible etiological factors. Acta Paediatr Scand 68, 587-92.

[21] Edery, P. (2007) Genetics of Hypospadias. Dialogues in Pediatric Urology 28, 3-6.

[22] (2010) London Dysmorphology Database, http://www.lmdatabases.com.

[23] Morgan, E.A., Nguyen, S.B., Scott, V. and Stadler, H.S. (2003) Loss of Bmp7 and Fgf8 signaling in Hoxa13-mutant mice causes hypospadia. Development 130, 3095 109.

[24] Mortlock, D.P. and Innis, J.W. (1997) Mutation of HOXA13 in hand-foot-genital syndrome. Nat Genet 15, 179-80.

[25] Frisen, L., Lagerstedt, K., Tapper-Persson, M., Kockum, I. and Nordenskjold, A. (2003) A novel duplication in the HOXA13 gene in a family with atypical hand-footgenital syndrome. J Med Genet 40, e49.

[26] Yucel, S., Liu, W., Cordero, D., Donjacour, A., Cunha, G. and Baskin, L.S. (2004) Anatomical studies of the fibroblast growth factor-10 mutant, Sonic Hedge Hog 
mutant and androgen receptor mutant mouse genital tubercle. Adv Exp Med Biol 545, 123-48.

[27] Petiot, A., Perriton, C.L., Dickson, C. and Cohn, M.J. (2005) Development of the mammalian urethra is controlled by Fgfr2-IIIb. Development 132, 2441-50.

[28] Beleza-Meireles, A., Lundberg, F., Lagerstedt, K., Zhou, X., Omrani, D., Frisen, L. and Nordenskjold, A. (2007) FGFR2, FGF8, FGF10 and BMP7 as candidate genes for hypospadias. Eur J Hum Genet 15, 405-10.

[29] Gao, F., Maiti, S., Alam, N., Zhang, Z., Deng, J.M., Behringer, R.R., Lecureuil, C., Guillou, F. and Huff, V. (2006) The Wilms tumor gene, Wt1, is required for Sox9 expression and maintenance of tubular architecture in the developing testis. Proc Natl Acad Sci U S A 103, 11987-92.

[30] Kohler, B., Delezoide, A.L., Boizet-Bonhoure, B., McPhaul, M.J., Sultan, C. and Lumbroso, S. (2007) Coexpression of Wilms' tumor suppressor 1 (WT1) and androgen receptor (AR) in the genital tract of human male embryos and regulation of AR promoter activity by WT1. J Mol Endocrinol 38, 547-54.

[31] Huang, B., Wang, S., Ning, Y., Lamb, A.N. and Bartley, J. (1999) Autosomal XX sex reversal caused by duplication of SOX9. Am J Med Genet 87, 349-53.

[32] Wang, Y., Li, Q., Xu, J., Liu, Q., Wang, W., Lin, Y., Ma, F., Chen, T., Li, S. and Shen, Y. (2004) Mutation analysis of five candidate genes in Chinese patients with hypospadias. Eur J Hum Genet 12, 706-12.

[33] Leipoldt, M., Erdel, M., Bien-Willner, G.A., Smyk, M., Theurl, M., Yatsenko, S.A., Lupski, J.R., Lane, A.H., Shanske, A.L., Stankiewicz, P. and Scherer, G. (2007) Two novel translocation breakpoints upstream of SOX9 define borders of the proximal and distal breakpoint cluster region in campomelic dysplasia. Clin Genet 71, 67-75.

[34] Maciel-Guerra, A.T., de Mello, M.P., Coeli, F.B., Ribeiro, M.L., Miranda, M.L., Marques-de-Faria, A.P., Baptista, M.T., Moraes, S.G. and Guerra-Junior, G. (2007) $\mathrm{XX}$ maleness and $\mathrm{XX}$ true hermaphroditism in SRY-negative monozygotic twins: additional evidence for a common origin. J Clin Endocrinol Metab.

[35] Ocal, G., Adiyaman, P., Berberoglu, M., Cetinkaya, E., Akar, N., Uysal, A., Duman, T., Evliyaoglu, O., Aycan, Z., Lumbroso, S. and Sultan, C. (2002) Mutations of the 5alpha-steroid reductase type 2 gene in six Turkish patients from unrelated families and a large pedigree of an isolated Turkish village. J Pediatr Endocrinol Metab 15, 411-21.

[36] Nicoletti, A., Baldazzi, L., Balsamo, A., Barp, L., Pirazzoli, P., Gennari, M., Radetti, G., Cacciari, E. and Cicognani, A. (2005) SRD5A2 gene analysis in an Italian population of under-masculinized 46,XY subjects. Clin Endocrinol (Oxf) 63, 375-80.

[37] Huhtaniemi, I. and Alevizaki, M. (2006) Gonadotrophin resistance. Best Pract Res Clin Endocrinol Metab 20, 561-76.

[38] Fukami, M., Wada, Y., Okada, M., Kato, F., Katsumata, N., Baba, T., Morohashi, K., Laporte, J., Kitagawa, M. and Ogata, T. (2008) Mastermind-like domain-containing 1 (MAMLD1 or CXorf6) transactivates the Hes3 promoter, augments testosterone production, and contains the SF1 target sequence. J Biol Chem 283, 5525-32.

[39] Fukami, M., Wada, Y., Miyabayashi, K., Nishino, I., Hasegawa, T., Nordenskjold, A., Camerino, G., Kretz, C., Buj-Bello, A., Laporte, J., Yamada, G., Morohashi, K. and Ogata, T. (2006) CXorf6 is a causative gene for hypospadias. Nat Genet 38, 1369-71.

[40] Kalfa, N., Liu, B., Ophir, K., Audran, F., Wang, M.H., Mei, C., Sultan, C. and Baskin, L.S. (2008) Mutations of CXorf6 are associated with a range of severities of hypospadias. Eur J Endocrinol 159, 453-8. 
[41] Chen, Y., Thai, H.T., Lundin, J., Lagerstedt-Robinson, K., Zhao, S., Markljung, E. and Nordenskjold, A. (2010) Mutational study of the MAMLD1-gene in hypospadias. Eur J Med Genet 53, 122-6.

[42] Kaspar, F., Cato, A.C., Denninger, A., Eberle, J., Radmayr, C., Glatzl, J., Bartsch, G. and Klocker, H. (1993) Characterization of two point mutations in the androgen receptor gene of patients with perineoscrotal hypospadia. J Steroid Biochem Mol Biol 47, 127-35.

[43] Sultan, C., Paris, F., Terouanne, B., Balaguer, P., Georget, V., Poujol, N., Jeandel, C., Lumbroso, S. and Nicolas, J.C. (2001) Disorders linked to insufficient androgen action in male children. Hum Reprod Update 7, 314-22.

[44] Holterhus, P.M., Werner, R., Struve, D., Hauffa, B.P., Schroeder, C. and Hiort, O. (2005) Mutations in the amino-terminal domain of the human androgen receptor may be associated with partial androgen insensitivity and impaired transactivation in vitro. Exp Clin Endocrinol Diabetes 113, 457-63.

[45] Hiort, O., Klauber, G., Cendron, M., Sinnecker, G.H., Keim, L., Schwinger, E., Wolfe, H.J. and Yandell, D.W. (1994) Molecular characterization of the androgen receptor gene in boys with hypospadias. Eur J Pediatr 153, 317-21.

[46] Sultan, C., Lumbroso, S., Poujol, N., Belon, C., Boudon, C. and Lobaccaro, J.M. (1993) Mutations of androgen receptor gene in androgen insensitivity syndromes. J Steroid Biochem Mol Biol 46, 519-30.

[47] Li, Q., Li, S.K., Xu, J.J., Wang, Y.P. and Shen, Y. (2004) [Study of genic mutations of androgen receptor in hypospadias]. Zhonghua Zheng Xing Wai Ke Za Zhi 20, 421-4.

[48] Deeb, A., Mason, C., Lee, Y.S. and Hughes, I.A. (2005) Correlation between genotype, phenotype and sex of rearing in 111 patients with partial androgen insensitivity syndrome. Clin Endocrinol (Oxf) 63, 56-62.

[49] Hayes, T.B., Collins, A., Lee, M., Mendoza, M., Noriega, N., Stuart, A.A. and Vonk, A. (2002) Hermaphroditic, demasculinized frogs after exposure to the herbicide atrazine at low ecologically relevant doses. Proc Natl Acad Sci U S A 99, 5476-80.

[50] Gray, L.E., Jr. and Kelce, W.R. (1996) Latent effects of pesticides and toxic substances on sexual differentiation of rodents. Toxicol Ind Health 12, 515-31.

[51] Henry, E.C., Miller, R.K. and Baggs, R.B. (1984) Direct fetal injections of diethylstilbestrol and 17 beta-estradiol: a method for investigating their teratogenicity. Teratology 29, 297-304.

[52] Gray, L.E., Ostby, J., Furr, J., Wolf, C.J., Lambright, C., Parks, L., Veeramachaneni, D.N., Wilson, V., Price, M., Hotchkiss, A., Orlando, E. and Guillette, L. (2001) Effects of environmental antiandrogens on reproductive development in experimental animals. Hum Reprod Update 7, 248-64.

[53] Baskin, L.S., Himes, K. and Colborn, T. (2001) Hypospadias and endocrine disruption: is there a connection? Environ Health Perspect 109, 1175-83.

[54] Fisher, J.S., Macpherson, S., Marchetti, N. and Sharpe, R.M. (2003) Human 'testicular dysgenesis syndrome': a possible model using in-utero exposure of the rat to dibutyl phthalate. Hum Reprod 18, 1383-94.

[55] Calzolari, E., Contiero, M.R., Roncarati, E., Mattiuz, P.L. and Volpato, S. (1986) Aetiological factors in hypospadias. J Med Genet 23, 333-7.

[56] Moretti, M., Magnani, C., Calzolari, E. and Roncarati, E. (1986) Genitourinary tract anomalies: neonatal medical problems. Fetal Ther 1, 114-5.

[57] Boisen, K.A., Chellakooty, M., Schmidt, I.M., Kai, C.M., Damgaard, I.N., Suomi, A.M., Toppari, J., Skakkebaek, N.E. and Main, K.M. (2005) Hypospadias in a cohort of 1072 Danish newborn boys: prevalence and relationship to placental weight, 
anthropometrical measurements at birth, and reproductive hormone levels at three months of age. J Clin Endocrinol Metab 90, 4041-6.

[58] Avellan, L. (1975) The incidence of hypospadias in Sweden. Scand J Plast Reconstr Surg 9, 129-39.

[59] Jeandel, C., Paris, F., Daures, J.P., Sultan, C. (2005) Environmental disruptors and disorders of the external genitals in male newborns : A case-control study. Horm. Res. 64, 128.

[60] Lund, L., Engebjerg, M.C., Pedersen, L., Ehrenstein, V., Norgaard, M. and Sorensen, H.T. (2009) Prevalence of hypospadias in Danish boys: a longitudinal study, 19772005. Eur Urol 55, 1022-6.

[61] Sun, G., Tang, D., Liang, J. and Wu, M. (2009) Increasing prevalence of hypospadias associated with various perinatal risk factors in chinese newborns. Urology 73, 12415.

[62] Fisch, H., Lambert, S.M., Hensle, T.W. and Hyun, G. (2009) Hypospadias rates in new york state are not increasing. J Urol 181, 2291-4.

[63] Fisch, H., Hyun, G. and Hensle, T.W. (2010) Rising hypospadias rates: disproving a myth. J Pediatr Urol 6, 37-9.

[64] Aho, M., Koivisto, A.M., Tammela, T.L. and Auvinen, A. (2000) Is the incidence of hypospadias increasing? Analysis of Finnish hospital discharge data 1970-1994. Environ Health Perspect 108, 463-5.

[65] Martinez-Frias, M.L., Prieto, D., Prieto, L., Bermejo, E., Rodriguez-Pinilla, E. and Cuevas, L. (2004) Secular decreasing trend of the frequency of hypospadias among newborn male infants in Spain. Birth Defects Res A Clin Mol Teratol 70, 75-81.

[66] Kristensen, P., Irgens, L.M., Andersen, A., Bye, A.S. and Sundheim, L. (1997) Birth defects among offspring of Norwegian farmers, 1967-1991. Epidemiology 8, 537-44.

[67] Weidner, I.S., Moller, H., Jensen, T.K. and Skakkebaek, N.E. (1999) Risk factors for cryptorchidism and hypospadias. J Urol 161, 1606-9.

[68] Weidner, I.S., Moller, H., Jensen, T.K. and Skakkebaek, N.E. (1998) Cryptorchidism and hypospadias in sons of gardeners and farmers. Environ Health Perspect 106, 793 6.

[69] Dolk, H., Vrijheid, M., Armstrong, B., Abramsky, L., Bianchi, F., Garne, E., Nelen, V., Robert, E., Scott, J.E., Stone, D. and Tenconi, R. (1998) Risk of congenital anomalies near hazardous-waste landfill sites in Europe: the EUROHAZCON study. Lancet 352, 423-7.

[70] Elliott, P., Briggs, D., Morris, S., de Hoogh, C., Hurt, C., Jensen, T.K., Maitland, I., Richardson, S., Wakefield, J. and Jarup, L. (2001) Risk of adverse birth outcomes in populations living near landfill sites. BMJ 323, 363-8.

[71] Mastroiacovo, P., Spagnolo, A., Marni, E., Meazza, L., Bertollini, R., Segni, G. and Borgna-Pignatti, C. (1988) Birth defects in the Seveso area after TCDD contamination. Jama 259, 1668-72.

[72] North, K. and Golding, J. (2000) A maternal vegetarian diet in pregnancy is associated with hypospadias. The ALSPAC Study Team. Avon Longitudinal Study of Pregnancy and Childhood. BJU Int 85, 107-13.

[73] Garry, V.F., Schreinemachers, D., Harkins, M.E. and Griffith, J. (1996) Pesticide appliers, biocides, and birth defects in rural Minnesota. Environ Health Perspect 104, 394-9.

[74] Garry, V.F., Harkins, M.E., Erickson, L.L., Long-Simpson, L.K., Holland, S.E. and Burroughs, B.L. (2002) Birth defects, season of conception, and sex of children born to pesticide applicators living in the Red River Valley of Minnesota, USA. Environ Health Perspect 110 Suppl 3, 441-9. 
[75] Hsieh, M.H., Breyer, B.N., Eisenberg, M.L. and Baskin, L.S. (2008) Associations among hypospadias, cryptorchidism, anogenital distance, and endocrine disruption. Curr Urol Rep 9, 137-42.

[76] Swan, S.H., Main, K.M., Liu, F., Stewart, S.L., Kruse, R.L., Calafat, A.M., Mao, C.S., Redmon, J.B., Ternand, C.L., Sullivan, S. and Teague, J.L. (2005) Decrease in anogenital distance among male infants with prenatal phthalate exposure. Environ Health Perspect 113, 1056-61.

[77] Klip, H., Verloop, J., van Gool, J.D., Koster, M.E., Burger, C.W. and van Leeuwen, F.E. (2002) Hypospadias in sons of women exposed to diethylstilbestrol in utero: a cohort study. Lancet 359, 1102-7.

[78] Kogevinas, M. (2001) Human health effects of dioxins: cancer, reproductive and endocrine system effects. Hum Reprod Update 7, 331-9.

[79] Santti, R., Makela, S., Strauss, L., Korkman, J. and Kostian, M.L. (1998) Phytoestrogens: potential endocrine disruptors in males. Toxicol Ind Health 14, 22337.

[80] Brock, J.W., Melnyk, L.J., Caudill, S.P., Needham, L.L. and Bond, A.E. (1998) Serum levels of several organochlorine pesticides in farmers correspond with dietary exposure and local use history. Toxicol Ind Health 14, 275-89.

[81] Olea, N., Olea-Serrano, F., Lardelli-Claret, P., Rivas, A. and Barba-Navarro, A. (1999) Inadvertent exposure to xenoestrogens in children. Toxicol Ind Health 15, 1518.

[82] Restrepo, M., Munoz, N., Day, N., Parra, J.E., Hernandez, C., Blettner, M. and Giraldo, A. (1990) Birth defects among children born to a population occupationally exposed to pesticides in Colombia. Scand J Work Environ Health 16, 239-46.

[83] Kelce, W.R., Stone, C.R., Laws, S.C., Gray, L.E., Kemppainen, J.A. and Wilson, E.M. (1995) Persistent DDT metabolite p,p'-DDE is a potent androgen receptor antagonist. Nature 375, 581-5.

[84] Sonawane, B.R. (1995) Chemical contaminants in human milk: an overview. Environ Health Perspect 103 Suppl 6, 197-205.

[85] Miyagawa, S., Katsu, Y., Ohta, Y., Sudo, T., Lubahn, D.B. and Iguchi, T. (2010) Estrogen receptor ESR1 is indispensable for the induction of persistent vaginal change by neonatal 5alpha-dihydrotestosterone exposure in mice. Biol Reprod 82, 497-503.

[86] Couse, J.F. and Korach, K.S. (2004) Estrogen receptor-alpha mediates the detrimental effects of neonatal diethylstilbestrol (DES) exposure in the murine reproductive tract. Toxicology 205, 55-63.

[87] Paris, F., Balaguer, P., Terouanne, B., Servant, N., Lacoste, C., Cravedi, J.P., Nicolas, J.C. and Sultan, C. (2002) Phenylphenols, biphenols, bisphenol-A and 4-tertoctylphenol exhibit alpha and beta estrogen activities and antiandrogen activity in reporter cell lines. Mol Cell Endocrinol 193, 43-9.

[88] Giwercman, A.H., Rignell-Hydbom, A., Toft, G., Rylander, L., Hagmar, L., Lindh, C., Pedersen, H.S., Ludwicki, J.K., Lesovoy, V., Shvets, M., Spano, M., Manicardi, G.C., Bizzaro, D., Bonefeld-Jorgensen, E.C. and Bonde, J.P. (2006) Reproductive hormone levels in men exposed to persistent organohalogen pollutants: a study of inuit and three European cohorts. Environ Health Perspect 114, 1348-53.

[89] Dechaud, H., Ravard, C., Claustrat, F., de la Perriere, A.B. and Pugeat, M. (1999) Xenoestrogen interaction with human sex hormone-binding globulin (hSHBG). Steroids 64, 328-34.

[90] Bredfeldt, T.G., Greathouse, K.L., Safe, S.H., Hung, M.C., Bedford, M.T. and Walker, C.L. (2010) Xenoestrogen-induced regulation of EZH2 and histone methylation via estrogen receptor signaling to PI3K/AKT. Mol Endocrinol 24, 993-1006. 
[91] Rider, C.V., Wilson, V.S., Howdeshell, K.L., Hotchkiss, A.K., Furr, J.R., Lambright, C.R. and Gray, L.E., Jr. (2009) Cumulative effects of in utero administration of mixtures of "antiandrogens" on male rat reproductive development. Toxicol Pathol 37, 100-13.

[92] Rider, C.V., Furr, J., Wilson, V.S. and Gray, L.E., Jr. (2008) A mixture of seven antiandrogens induces reproductive malformations in rats. Int J Androl 31, 249-62.

[93] Main, K.M., Skakkebaek, N.E., Virtanen, H.E. and Toppari, J. (2010) Genital anomalies in boys and the environment. Best Pract Res Clin Endocrinol Metab 24, 279-89.

[94] Guyot, R., Odet, F., Leduque, P., Forest, M.G. and Le Magueresse-Battistoni, B. (2004) Diethylstilbestrol inhibits the expression of the steroidogenic acute regulatory protein in mouse fetal testis. Mol Cell Endocrinol 220, 67-75.

[95] Kim, K.S., Torres, C.R., Jr., Yucel, S., Raimondo, K., Cunha, G.R. and Baskin, L.S. (2004) Induction of hypospadias in a murine model by maternal exposure to synthetic estrogens. Environ Res 94, 267-75.

[96] McKinnell, C., Atanassova, N., Williams, K., Fisher, J.S., Walker, M., Turner, K.J., Saunders, T.K. and Sharpe, R.M. (2001) Suppression of androgen action and the induction of gross abnormalities of the reproductive tract in male rats treated neonatally with diethylstilbestrol. J Androl 22, 323-38.

[97] McKee, R.H., Pavkov, K.L., Trimmer, G.W., Keller, L.H. and Stump, D.G. (2006) An assessment of the potential developmental and reproductive toxicity of di-isoheptyl phthalate in rodents. Reprod Toxicol 21, 241-52.

[98] Plummer, S., Sharpe, R.M., Hallmark, N., Mahood, I.K. and Elcombe, C. (2007) Time-dependent and compartment-specific effects of in utero exposure to Di(n-butyl) phthalate on gene/protein expression in the fetal rat testis as revealed by transcription profiling and laser capture microdissection. Toxicol Sci 97, 520-32.

[99] Habert, R., Muczynski, V., Lehraiki, A., Lambrot, R., Lecureuil, C., Levacher, C., Coffigny, H., Pairault, C., Moison, D., Frydman, R. and Rouiller-Fabre, V. (2009) Adverse effects of endocrine disruptors on the foetal testis development: focus on the phthalates. Folia Histochem Cytobiol 47, S67-74.

[100] Cook, J.C., Mullin, L.S., Frame, S.R. and Biegel, L.B. (1993) Investigation of a mechanism for Leydig cell tumorigenesis by linuron in rats. Toxicol Appl Pharmacol 119, 195-204.

[101] McIntyre, B.S., Barlow, N.J., Wallace, D.G., Maness, S.C., Gaido, K.W. and Foster, P.M. (2000) Effects of in utero exposure to linuron on androgen-dependent reproductive development in the male $\mathrm{Crl}: \mathrm{CD}(\mathrm{SD}) \mathrm{BR}$ rat. Toxicol Appl Pharmacol 167, 87-99.

[102] Takeda, T., Matsumoto, Y., Koga, T., Mutoh, J., Nishimura, Y., Shimazoe, T., Ishii, Y., Ishida, T. and Yamada, H. (2009) Maternal exposure to dioxin disrupts gonadotropin production in fetal rats and imprints defects in sexual behavior. $\mathrm{J}$ Pharmacol Exp Ther 329, 1091-9.

[103] Taketoh, J., Mutoh, J., Takeda, T., Ogishima, T., Takeda, S., Ishii, Y., Ishida, T. and Yamada, H. (2007) Suppression of fetal testicular cytochrome P450 17 by maternal exposure to 2,3,7,8-tetrachlorodibenzo-p-dioxin: a mechanism involving an initial effect on gonadotropin synthesis in the pituitary. Life Sci 80, 1259-67.

[104] Wang, Z., Liu, B.C., Lin, G.T., Lin, C.S., Lue, T.F., Willingham, E. and Baskin, L.S. (2007) Up-regulation of estrogen responsive genes in hypospadias: microarray analysis. J Urol 177, 1939-46. 
[105] Liu, B., Wang, Z., Lin, G., Agras, K., Ebbers, M., Willingham, E. and Baskin, L.S. (2005) Activating transcription factor 3 is up-regulated in patients with hypospadias. Pediatr Res 58, 1280-3.

[106] Liu, B., Lin, G., Willingham, E., Ning, H., Lin, C.S., Lue, T.F. and Baskin, L.S. (2007) Estradiol upregulates activating transcription factor 3, a candidate gene in the etiology of hypospadias. Pediatr Dev Pathol 10, 446-54.

[107] Liu, B., Agras, K., Willingham, E., Vilela, M.L. and Baskin, L.S. (2006) Activating transcription factor 3 is estrogen-responsive in utero and upregulated during sexual differentiation. Horm Res 65, 217-22.

[108] Liu, X., Zhang, D.Y., Li, Y.S., Xiong, J., He, D.W., Lin, T., Li, X.L. and Wei, G.H. (2009) Di-(2-ethylhexyl) phthalate upregulates ATF3 expression and suppresses apoptosis in mouse genital tubercle. J Occup Health 51, 57-63.

[109] Willingham, E. and Baskin, L.S. (2007) Candidate genes and their response to environmental agents in the etiology of hypospadias. Nat Clin Pract Urol 4, 270-9.

[110] Agras, K., Willingham, E., Shiroyanagi, Y., Minasi, P. and Baskin, L.S. (2007) Estrogen receptor-alpha and beta are differentially distributed, expressed and activated in the fetal genital tubercle. J Urol 177, 2386-92.

[111] Aschim, E.L., Nordenskjold, A., Giwercman, A., Lundin, K.B., Ruhayel, Y., Haugen, T.B., Grotmol, T. and Giwercman, Y.L. (2004) Linkage between cryptorchidism, hypospadias, and GGN repeat length in the androgen receptor gene. J Clin Endocrinol Metab 89, 5105-9.

[112] Radpour, R., Rezaee, M., Tavasoly, A., Solati, S. and Saleki, A. (2007) Association of long polyglycine tracts (GGN repeats) in exon 1 of the androgen receptor gene with cryptorchidism and penile hypospadias in Iranian patients. J Androl 28, 164-9.

[113] Muroya, K., Sasagawa, I., Suzuki, Y., Nakada, T., Ishii, T. and Ogata, T. (2001) Hypospadias and the androgen receptor gene: mutation screening and CAG repeat length analysis. Mol Hum Reprod 7, 409-13.

[114] Lim, H.N., Chen, H., McBride, S., Dunning, A.M., Nixon, R.M., Hughes, I.A. and Hawkins, J.R. (2000) Longer polyglutamine tracts in the androgen receptor are associated with moderate to severe undermasculinized genitalia in XY males. Hum Mol Genet 9, 829-34.

[115] Thai, H.T., Kalbasi, M., Lagerstedt, K., Frisen, L., Kockum, I. and Nordenskjold, A. (2005) The valine allele of the V89L polymorphism in the 5-alpha-reductase gene confers a reduced risk for hypospadias. J Clin Endocrinol Metab 90, 6695-8.

[116] van der Zanden, L.F., van Rooij, I.A., Feitz, W.F., Vermeulen, S.H., Kiemeney, L.A., Knoers, N.V., Roeleveld, N. and Franke, B. (2010) Genetics of hypospadias: are single-nucleotide polymorphisms in SRD5A2, ESR1, ESR2, and ATF3 really associated with the malformation? J Clin Endocrinol Metab 95, 2384-90.

[117] Watanabe, M., Yoshida, R., Ueoka, K., Aoki, K., Sasagawa, I., Hasegawa, T., Sueoka, K., Kamatani, N., Yoshimura, Y. and Ogata, T. (2007) Haplotype analysis of the estrogen receptor 1 gene in male genital and reproductive abnormalities. Hum Reprod 22, 1279-84.

[118] Ban, S., Sata, F., Kurahashi, N., Kasai, S., Moriya, K., Kakizaki, H., Nonomura, K. and Kishi, R. (2008) Genetic polymorphisms of ESR1 and ESR2 that may influence estrogen activity and the risk of hypospadias. Hum Reprod 23, 1466-71.

[119] Beleza-Meireles, A., Kockum, I., Lundberg, F., Soderhall, C. and Nordenskjold, A. (2007) Risk factors for hypospadias in the estrogen receptor 2 gene. J Clin Endocrinol Metab 92, 3712-8.

[120] Kalfa, N., Liu, B., Klein, O., Wang, M.H., Cao, M. and Baskin, L.S. (2008) Genomic variants of ATF3 in patients with hypospadias. J Urol 180, 2183-8; discussion 2188. 
[121] Reik, W., Dean, W. and Walter, J. (2001) Epigenetic reprogramming in mammalian development. Science 293, 1089-93.

[122] Durcova-Hills, G., Ainscough, J. and McLaren, A. (2001) Pluripotential stem cells derived from migrating primordial germ cells. Differentiation 68, 220-6.

[123] Hajkova, P., Erhardt, S., Lane, N., Haaf, T., El-Maarri, O., Reik, W., Walter, J. and Surani, M.A. (2002) Epigenetic reprogramming in mouse primordial germ cells. Mech Dev 117, 15-23.

[124] Anway, M.D., Cupp, A.S., Uzumcu, M. and Skinner, M.K. (2005) Epigenetic transgenerational actions of endocrine disruptors and male fertility. Science 308, 1466-9.

[125] Ormond, G., Nieuwenhuijsen, M.J., Nelson, P., Toledano, M.B., Iszatt, N., Geneletti, S. and Elliott, P. (2009) Endocrine disruptors in the workplace, hair spray, folate supplementation, and risk of hypospadias: case-control study. Environ Health Perspect 117, 303-7.

[126] Longnecker, M.P., Klebanoff, M.A., Brock, J.W., Zhou, H., Gray, K.A., Needham, L.L. and Wilcox, A.J. (2002) Maternal serum level of 1,1-dichloro-2,2-bis(pchlorophenyl)ethylene and risk of cryptorchidism, hypospadias, and polythelia among male offspring. Am J Epidemiol 155, 313-22.

[127] Small, C.M., DeCaro, J.J., Terrell, M.L., Dominguez, C., Cameron, L.L., Wirth, J. and Marcus, M. (2009) Maternal exposure to a brominated flame retardant and genitourinary conditions in male offspring. Environ Health Perspect 117, 1175-9.

[128] McGlynn, K.A., Guo, X., Graubard, B.I., Brock, J.W., Klebanoff, M.A. and Longnecker, M.P. (2009) Maternal pregnancy levels of polychlorinated biphenyls and risk of hypospadias and cryptorchidism in male offspring. Environ Health Perspect 117, 1472-6.

[129] Rocheleau, C.M., Romitti, P.A. and Dennis, L.K. (2009) Pesticides and hypospadias: a meta-analysis. J Pediatr Urol 5, 17-24. 
Table 1

\begin{tabular}{|c|l|}
\hline Gene & \multicolumn{1}{c|}{ Variants } \\
\hline AR & - CAG/GGN repeat length polymorphism \\
\hline & - A49T, \\
\hline SRD5A2 & - L113V \\
& - H231R \\
& - V89L \\
\hline HSD17B3 & - S232L \\
\hline ESR1 & - G allele containing variants of ESR1 Xbal \\
\hline ESR2 & - G allele containing variants of ESR2 2681-4A>G \\
& - (CA)n polymorphism in intron 6 \\
\hline & - Specific 'TTC' haplotype in intron 1 \\
& - c.536A > G(R90) \\
\hline ATF3 & -817 C $>$ T in the 3'-UTR. \\
& - L23M, \\
& - C53070T, \\
& - C53632A, \\
& - lns53943A \\
\hline MAMLD1/CXorf6 & - V432A \\
& - CAG10 > CAG13 \\
\hline
\end{tabular}




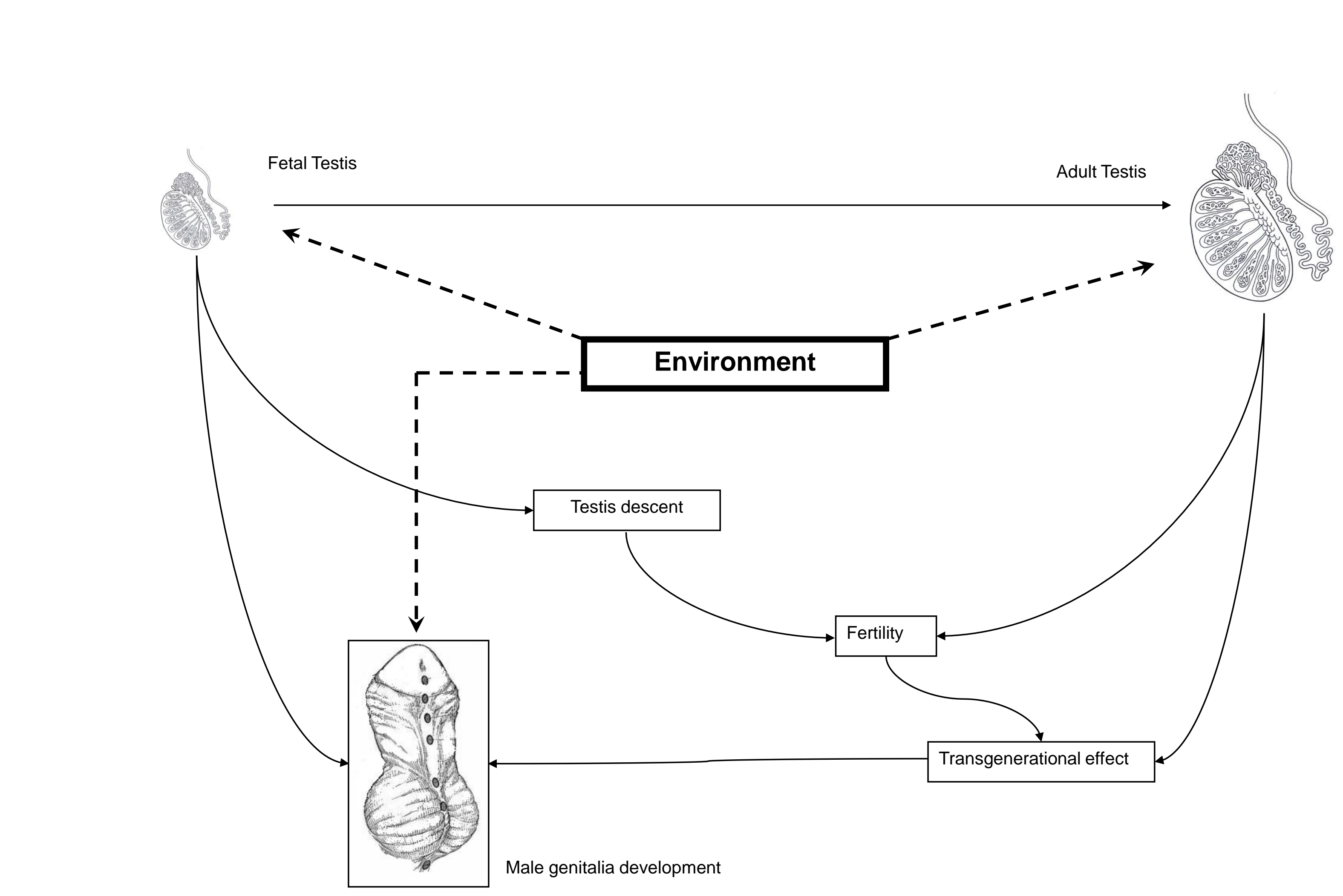

Environment

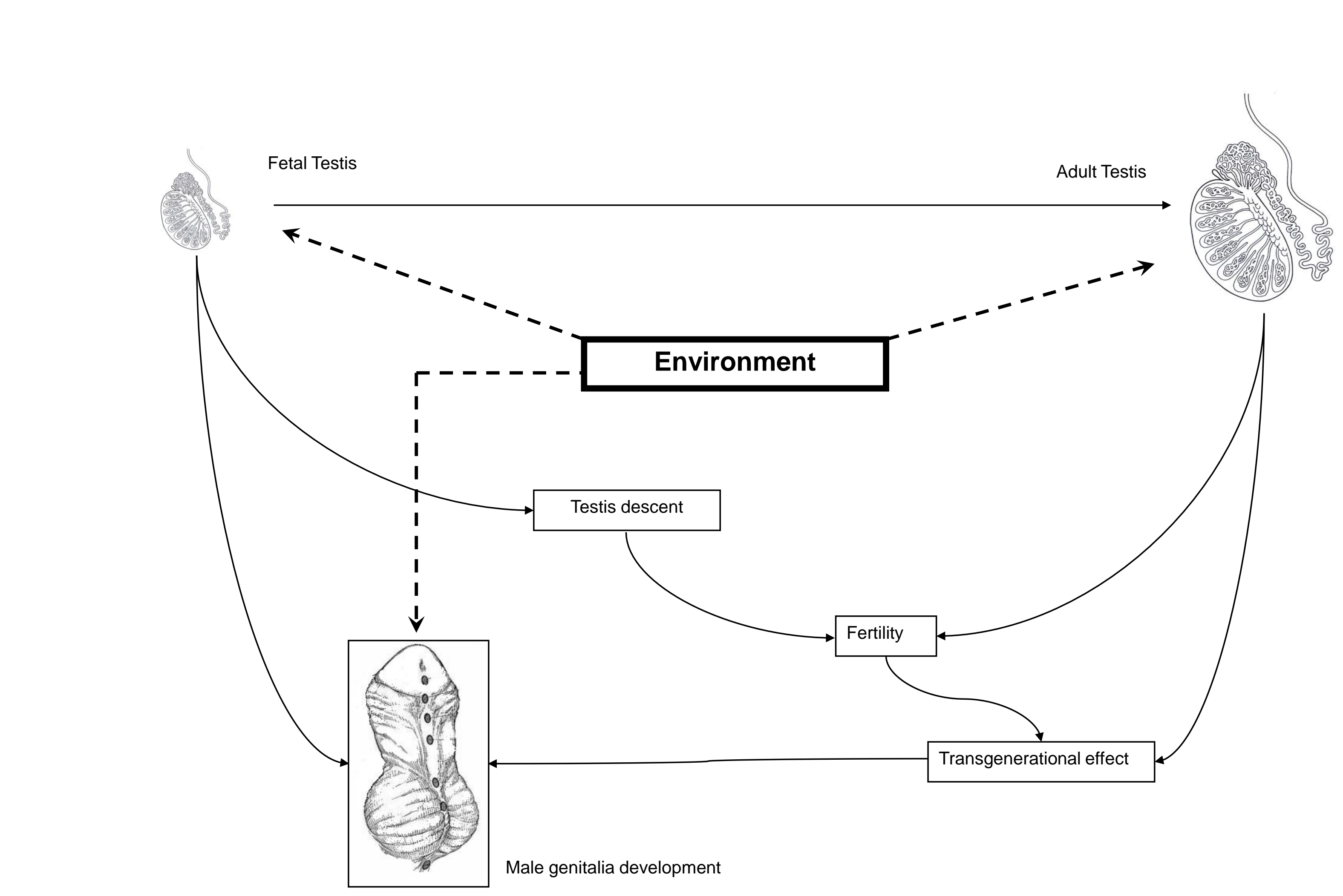

